\title{
Pathogenesis of Hypocalcemia in Magnesium Depletion
}

\author{
NORMAL END-ORGAN RESPONSIVENESS TO PARATHYROID HORMONE
}

\author{
Se Mo Suh, Adele Csima, and Donald Fraser \\ From the Departments of Paediatrics, Physiology, and Epidemiology and \\ Biometrics, University of Toronto, and the Research Institute, The Hospital \\ for Sick Children, Toronto, Ontario, Canada
}

\begin{abstract}
A в S T R A C T Hypocalcemia in the hypomagnesemic state in man is usually attributed to refractoriness of end-organs to the calcemic action of parathyroid hormone. We studied the responsiveness of end-organs to bovine parathyroid extract (PTE) in magnesium-depleted and control dogs by the following three methods after thyroparathyroidectomy: (a) assessment of the calcemic response to a set dose of PTE $(0.3 \mathrm{U} / \mathrm{kg}$ per hr) ; (b) assessment of PTE dose required to attain normocalcemia; $(c)$ evaluation of regression lines of plasma calcium concentration on PTE dose. The calcemic response of magnesium-depleted thyroparathyroidectomized puppies to a set dose of PTE was similar to that of control puppies. There was no significant difference in the dose of PTE required to attain normocalcemia nor in the dose-response relations between the plasma calcium concentration and the PTE dose. In a group of magnesium-depleted puppies with intact thyroid and parathyroid glands, the dose of PTE required to attain normocalcemia was similar to that required in thyroparathyroidectomized animals, indicating calcitonin was not a factor contributing to hypocalcemia. We conclude that hypocalcemia in magnesium-depleted puppies is not due to refractoriness of end-organs to the calcium-mobilizing action of parathyroid hormone. Defective synthesis or diminished secretion of parathyroid hormone is suggested as an explanation.
\end{abstract}

A preliminary report of this work has been published as an abstract (1).

Dr. Suh is a student at the School of Graduate Studies, University of Toronto, and a Research Fellow at the Research Institute, The Hospital for Sick Children. Mrs. Csima is an Assistant Professor, Epidemiology and Biometrics at the School of Hygiene, University of Toronto. Dr. Fraser is an Associate Professor, Departments of Paediatrics and Physiology, University of Toronto, and is a Senior Scientist at the Research Institute, The Hospital for Sick Children.

Received for publication 7 April 1971 and in revised form 2 August 1971.

\section{INTRODUCTION}

Hypocalcemia is a frequent feature of magnesium depletion in man (2) and several other species of animals: $\operatorname{dog}(3,4)$, cow $(5,6)$, pig (7), and sheep (8). A study from this hospital of a critically ill newborn infant demonstrated that the hypocalcemia was secondary to hypomagnesemia $(9,10)$ and prompted us to investigate the pathogenesis of hypocalcemia in the state of magnesium depletion.

Hypocalcemia, from whatever cause, would be expected to stimulate secretion of parathyroid hormone; parathyroid hormone would, in turn, reestablish a normal plasma calcium level except in extreme situations. Amongst various possibilities, failure to correct hypocalcemia in magnesium depletion could be accounted for by any of the following mechanisms involving parathyroid physiology: $(a)$ diminished responsiveness of endorgans to parathyroid hormone, $(b)$ excessive inactivation of circulating parathyroid hormone, $(c)$ impaired synthesis or diminished secretion of hormone by the parathyroid glands.

The present study assesses the responsiveness of magnesium-depleted puppies to parathyroid hormone and was undertaken to clarify the role of the parathyroid glands in the pathogenesis of hypocalcemia in magnesium depletion.

\section{METHODS}

Responsiveness to parathyroid hormone was assessed by three criteria, one or more of which were applied in three different studies. The experimental design is summarized in Table I.

Animals. All experiments were performed in female dogs. In study I, the dogs were of various ages, and not necessarily of a single breed. In studies II and III, only purebred beagles ${ }^{1}$ were studied. Each animal was housed

\footnotetext{
${ }^{1}$ Purchased from Marshall Experimental Farm, North Rose, N. Y.
} 
TABLE I

General Outline of the Studies

\begin{tabular}{|c|c|c|c|c|c|c|}
\hline & Species & Dogs & $\begin{array}{l}\text { Initial } \\
\text { age }\end{array}$ & $\begin{array}{l}\text { Duration } \\
\text { of diet }\end{array}$ & TX PTX & Tests \\
\hline & & $n$ & & $w k$ & & \\
\hline \multicolumn{7}{|l|}{ Study I } \\
\hline Control & $\begin{array}{l}\text { Beagle } \\
\text { Mongrel }\end{array}$ & $\begin{array}{r}10 \\
1\end{array}$ & $10 \mathrm{wk}-7 \mathrm{yr}$ & $3-28$ & yes & PTE requirement to attain normocalcemia. \\
\hline Mg-depleted & $\begin{array}{l}\text { Beagle } \\
\text { Mongrel }\end{array}$ & $\begin{array}{c}4 \\
2 \\
\text { (Paired }\end{array}$ & $\begin{array}{l}\quad 21-43 \text { wk } \\
\text { studies in four se }\end{array}$ & $\begin{array}{l}\text { 4-28 } \\
\text { ets only) }\end{array}$ & yes & \\
\hline $\begin{array}{l}\text { Study II } \\
\text { Control } \\
\text { Mg-depleted }\end{array}$ & Beagle & 4 pairs & $\begin{array}{c}9 \text { wk } \\
\text { (Paired studies) }\end{array}$ & 6 & yes & $\begin{array}{l}\text { (a) Calcemic response to PTE } 0.3 \mathrm{U} / \mathrm{kg} \text { per } \mathrm{hr} \text {. } \\
\text { (b) PTE requirement to attain normocalcemia. } \\
\text { (c) Regression analysis of plasma } \mathrm{Ca} \text { on PTE } \\
\text { dose. }\end{array}$ \\
\hline $\begin{array}{l}\text { Study III } \\
\text { Control } \\
\text { Mg-depleted }\end{array}$ & Beagle & 5 pairs & $\begin{array}{c}\text { 8-19 wk } \\
\text { (Paired studies) }\end{array}$ & $7-27$ & no & $\begin{array}{l}\text { PTE requirement to attain normocalcemia (in } \\
\mathrm{Mg} \text {-depleted animals only). }\end{array}$ \\
\hline
\end{tabular}

in a special metabolic cage. The room temperature was kept constant at $23^{\circ} \mathrm{C}$.

Diet. Synthetic magnesium-deficient and magnesium-supplemented diets were used. Their composition is shown in Table II and the mineral content in Table III. The diets were similar to those of Bunce, Jenkins, and Phillips (3), but the vitamin and mineral contents were modified. In particular, the amount of magnesium in the supplemented diet ("control diet") was increased to $73 \mathrm{mg} / 100 \mathrm{~g}$ diet, to ensure that animals had an adequate intake of mag-

TABLE II

Composition of the Diets

\begin{tabular}{cc}
\hline & $k g / 100 \mathrm{~g}$ diet \\
Magnesium-deficient diet & \\
Casein* & 19.0 \\
Glucose & 60.0 \\
Corn oil & 7.0 \\
Vitamin mixture & 2.0 \\
Salt mixture§ & 5.5 \\
Alpha-cell & 6.5
\end{tabular}

Magnesium-supplemented diet (control diet)

$400 \mathrm{mg}$ anhydrous $\mathrm{MgSO}_{4}$ were added to $100 \mathrm{~g}$ of above diet.

\footnotetext{
* Vitamin-free casein, Nutritional Biochemicals Corporation, Cleveland, Ohio.

$\ddagger$ Vitamin Diet Fortification Mixture, Nutritional Biochemicals Corporation.

$\$ 5.5 \mathrm{~g}$ of salt mixture consisted of $\mathrm{KCl}, 1.14 \mathrm{~g} ; \mathrm{NaCl}, 1.00 \mathrm{~g}$; $\mathrm{CaHPO}_{4}, 2.19 \mathrm{~g} ; \mathrm{Na}_{2} \mathrm{HPO}_{4}$, anhydrous $1.15 \mathrm{~g} ; \mathrm{Fe}\left(\mathrm{SO}_{4}\right)_{3}$, $36 \mathrm{mg} ; \mathrm{CuSO}_{4} \cdot 5 \mathrm{H}_{2} \mathrm{O}, 2.75 \mathrm{mg} ; \mathrm{MnSO}_{4} \cdot \mathrm{H}_{2} \mathrm{O}, 1.54 \mathrm{mg}$; $\mathrm{ZnCl}_{2}$ (dry), $2.08 \mathrm{mg} ; \mathrm{KI}, 0.13 \mathrm{mg}$; $\mathrm{CoCl}_{2} \cdot 6 \mathrm{H}_{2} \mathrm{O}, 0.88 \mathrm{mg}$.
}

nesium $^{2}$ even when, as a result of pair-feeding, the amount of food offered was restricted. The nutritional adequacy of the control diet was established in a pilot study. ${ }^{3}$ In preparing the diet for feeding, an equal amount of distilled water was admixed. For drinking, distilled water was provided ad lib. in a separate bowl.

All dogs on the magnesium-deficient diet ("magnesiumdepleted dogs") developed significant hypomagnesemia and hypocalcemia; the dogs on the control diet ("control dogs") remained normomagnesemic and normocalcemic.

The "normocalcemic value." The base line plasma calcium concentration of each control dog was taken as the

The minimum intake of magnesium for adequate nutrition in the dog is stated by Kahil, Parrish, Simons, and Brown (11) to be $16 \mathrm{mg} / \mathrm{kg}$ body weight per day, and estimated by Bunce et al. (3) to be approximately $14 \mathrm{mg} /$ $100 \mathrm{~g}$ diet.

Three pairs of beagle puppies were fed ad lib., one animal of each pair receiving the magnesium-supplemented diet, the other receiving a commercial dog chow diet. The average weight at the end of the 6th wk on the diets increased from the initial weight $(2.7 \mathrm{~kg}$ in each group) to $7.7 \mathrm{~kg}$ in the group fed the magnesium-supplemented diet and to $7.1 \mathrm{~kg}$ in the group fed the chow diet.

TABLE III

Mineral Content of the Diets (by Analysis)

\begin{tabular}{lcc} 
& Control diet & \multicolumn{2}{c}{ Magnesium-deficient diet } \\
\hline $\mathrm{Ca}$ & 600 & $m \mathrm{~g} / 100 \mathrm{~g}$ diet \\
$\mathrm{Mg}$ & 73 & 600 \\
$\mathrm{P}$ & 730 & 0.3 \\
$\mathrm{Na}$ & 680 & 730 \\
$\mathrm{~K}$ & 880 & 680 \\
& & 880 \\
\hline
\end{tabular}


"normocalcemic value" for that animal and for the corresponding paired magnesium-depleted dog. In studies I and III, the average of the last three weekly plasma calcium values obtained in the control animal before thyroparathyroidectomy was chosen as the "normocalcemic value" because plasma calcium concentrations were relatively constant from week to week. In study II, the method of deriving the normocalcemic value was modified to take into account the diurnal variation observed in plasma calcium concentration. During the 6th wk on the experimental diets, plasma calcium values were determined for each control puppy twice daily ( 9 a.m. and 4 p.m.) for 6 days and the average of these values was taken as the normocalcemic value for that pair. The method used to determine the normocalcemic value in study II was somewhat more complex than that used in studies I and III but when the normocalcemic values derived by each of the methods were compared in the six control puppies of study II, no significant difference was observed.

Thyroparathyroidectomy. Animals, fasted from 4 p.m. the previous day, were given Innovar-Vet, ${ }^{4} 0.1 \mathrm{ml} / \mathrm{kg}$ intramuscularly, as a preoperative medication and anesthetized by Fluothane (bromochlorotrifluoroethane) ${ }^{5}$ inhalation. In thyroparathyroidectomized animals, complete removal of the parathyroid glands was confirmed by identifying the four glands at the time of operation, and by observing a decrease of the plasma calcium concentration $6 \mathrm{hr}$ postoperatively, ${ }^{6}$ and a further decrease in the plasma calcium level after terminating the parathyroid extract $(\mathrm{PTE})^{7}$ infusion.

Starting at the time of thyroparathyroidectomy, L-thyroxine, $0.05 \mathrm{mg}$, was given daily to each puppy as replacement therapy. On this dose, the levels of serum thyroxine and cholesterol were comparable to preoperative values for control and magnesium-depleted puppies.

Technique for prolonged, constant intravenous administration of fluid. The left jugular vein was cannulated using an indwelling Silastic tube brought out through the skin incision. The tube was connected to a special infusion device, the lower end of which was secured to the dog's back by a halter, and the upper end attached to a swivel at the top of the metabolic cage. In this way it was possible to deliver fluid intravenously to an otherwise unrestrained dog for up to $4 \mathrm{wk}$.

Administration of PTE. $\mathrm{PTE}^{8}$ was administered by constant intravenous infusion. The amount required for a $48-\mathrm{hr}$ period was mixed with $480 \mathrm{ml}$ of $3.3 \%$ glucose in $0.3 \%$ saline, and this solution was infused at a rate of 10 $\mathrm{ml} / \mathrm{hr}$ by means of a Sigmamotor pump. ${ }^{\circ}$ The stability of diluted PTE was verified by testing its potency by the Munson rat-bioassay (12) after keeping the hormone at room temperature for $48 \mathrm{hr}$.

Calculation of PTE dose to attain normocalcemia. Each control and magnesium-depleted dog was infused with

4 McNeil Laboratories (Canada) Limited, Don Mills, Ontario, Canada.

${ }^{5}$ Ayerst, McKenna \& Harrison Ltd., Montreal, Quebec, Canada.

${ }^{B}$ Observation for a longer period was not attempted at this stage in the experiment because of the risk of death from hypocalcemia.

${ }^{7}$ Abbreviation used in this paper: PTE, parathyroid extract.

${ }^{8}$ Para-Thor-Mone. Eli Lilly and Company (Canada) Limited, Toronto. Batch 2LP99C was used throughout this study. Doses quoted are in USP units.

${ }^{\circ}$ Sigmamotor Inc, Middleport, N. Y. graded doses of PTE, adjusted stepwise every $48 \mathrm{hr}$ within the range of $0.2-0.5 \mathrm{U} / \mathrm{kg}$ per hr until a plasma calcium value of approximately $6 \mathrm{mEq} /$ liter was attained. Plasma calcium values were determined four times, at $17,24,41$, and $48 \mathrm{hr}$ for each dose level of PTE. Because the four plasma calcium values did not differ significantly with respect to time (by analysis of variance in each group), the mean of the four values was taken as the plasma calcium concentration for that animal at that level of PTE dose. The dose of PTE required to attain the "normocalcemic value" for a given animal was calculated from the regression equation relating plasma calcium concentration and $\log$ dose of PTE for that animal.

Chemical determinations. Concentrations of magnesium and calcium in the plasma and in ashed samples of diet were determined by atomic absorption and flame emission spectrophotometry respectively $(13,14)$. The coefficients of variation of replicate estimations of plasma magnesium and calcium were $1 \%$. Concentrations of inorganic phosphate in the plasma and in ashed samples of diet were determined by the Gomori method (15) using an AutoAnalyzer. ${ }^{10}$ The coefficient of variation was $1.9 \%$. Plasma alkaline phosphatase activity was assayed by the method of King and Armstrong (16). Calcium ion activity of plasma was determined using a calcium-specific flow-through ion exchange electrode ${ }^{11}$ (17). Other determinations were carried out by standard methods.

Statistical methods. The results are given as mean \pm 1 SD. Student's $t$ test, analysis of variance, and regression analysis were performed by standard formulas (18) using an IBM 7094 computer.

\section{EXPERIMENTS AND RESULTS}

\section{Study I}

\section{EXPERIMENT}

The dose of PTE required to attain normocalcemia after thyroparathyroidectomy was assessed in control and magnesium-depleted dogs of various ages. Experimental diets were fed for 3-28 wk before thyroparathyroidectomy. The food intake of control animals was restricted to approximately that of magnesium-depleted animals. The series comprised 11 control and 6 magnesium-depleted animals, aged $10 \mathrm{wk}-7 \mathrm{yr}$, and included 14 beagles and 3 mongrels. Four pairs were litter-mates and permitted a paired comparison of control and magnesiumdepleted animals.

\section{Results}

In animals fed on the control diet, plasma magnesium and calcium concentrations remained constant throughout the period of feeding and averaged $1.50 \mathrm{mEq} /$ liter and $5.84 \mathrm{mEq} /$ liter respectively. Plasma magnesium concentration was not affected by the age of the animals but plasma calcium concentrations in two older animals (age 6 and $7 \mathrm{yr}$ ) were somewhat lower than the values in young dogs.

\footnotetext{
${ }^{10}$ Technicon Instruments Corporation, Ardsley, N. Y. ${ }^{11}$ Model 99-20. Orion Research, Inc, Cambridge, Mass.
} 
TABLE IV A

Dose of PTE Required to Attain the "Normocalcemic Value" in Control and Mg-Depleted

Dogs of Various Ages

Study I, all dogs included

\begin{tabular}{ccccc}
\hline Dog No. & $\begin{array}{c}\text { Initial } \\
\text { age }\end{array}$ & $\begin{array}{c}\text { Duration } \\
\text { of diet }\end{array}$ & $\begin{array}{c}\text { Normocalcemic } \\
\text { value }\end{array}$ & $\begin{array}{c}\text { PTE dose } \\
\text { required }\end{array}$ \\
\hline Control dogs & $w k$ & $w k$ & $m E q /$ liter & U/kg per $h r$ \\
C 1 & 10 & 3 & 5.95 & 0.38 \\
C 2 & 10 & 3 & 6.14 & 0.50 \\
C 3 & 16 & 8 & 5.85 & 0.27 \\
C 4 & 17 & 7 & 5.99 & 0.57 \\
C 6 & 22 & 4 & 5.96 & 0.58 \\
C 8 & 24 & 15 & 6.10 & 0.20 \\
C $9 *$ & 33 & 22 & 5.80 & 0.23 \\
C 10 & 34 & 3 & 5.68 & 0.28 \\
C 11 & 36 & 28 & 5.78 & 0.63 \\
C 13 & 6 yr & 6 & 5.49 & 0.49 \\
C 14 & 7 yr & 6 & 5.48 & 0.63 \\
Mean \pm sD & & & & $0.43 \pm 0.17$ \\
Mg-depleted dogs & & & & \\
E 5 5 & 21 & 9 & 5.65 & 0.62 \\
E 6 & 22 & 4 & 5.96 & 0.41 \\
E 7 & 23 & 5 & 5.96 & 0.31 \\
E 8 & 24 & 15 & 6.10 & 0.22 \\
E $9 *$ & 33 & 22 & 5.80 & 0.41 \\
E $12^{*}$ & 43 & 28 & 6.08 & 0.29 \\
Mean \pm sD & & & & $0.38 \pm 0.14$ \\
\hline
\end{tabular}

* Mongrel.

In animals fed the magnesium-deficient diet, plasma magnesium and calcium concentrations decreased to about $0.5 \mathrm{mEq} /$ liter and $4.5 \mathrm{mEq} /$ liter respectively by the $3 \mathrm{rd}$ wk on the diet regardless of the age of the animals, then the values remained constant during the period of magnesium depletion which in some cases was as long as $28 \mathrm{wk}$.

The dose of PTE required to attain normocalcemia in control and magnesium-depleted dogs was compared in two ways. Considering all the animals in this study (Table IVA), the mean PTE requirement of control dogs was $0.43 \pm 0.17 \mathrm{U} / \mathrm{kg}$ per $\mathrm{hr}$ and of magnesiumdepleted dogs was $0.38 \pm 0.14 \mathrm{U} / \mathrm{kg}$ per $\mathrm{hr}$; these values were not significantly different. Comparing the four matched pairs of litter-mate dogs (Table IVB) there was, similarly, no significant difference in PTE requirement (by paired $t$ test). Regression analysis of PTE requirement on age showed no correlation, indicating that PTE requirement expressed on a unit-weight basis is not affected by the age of animals. Similarly, regression analysis of PTE requirement on duration of experimental diet revealed no correlation whether for control or magnesium-depleted animals. The PTE requirement to attain normocalcemia in the mongrel dogs in this study fell within the range observed in beagles.
This study failed to demonstrate any significant difference in end-organ responsiveness to the calcemic action of PTE when judged on the basis of PTE require-

TABLE IV B

Dose of PTE Required to Attain the "Normocalcemic Value" in Control and Mg-Depleted Dogs of Various Ages Study I, paired comparison

\begin{tabular}{cccc}
\hline & \multicolumn{3}{c}{ PTE dose required } \\
\cline { 2 - 4 } Experimental pair & Control & Mg-depleted & $\Delta^{*}$ \\
\hline & & U/kg per hr & \\
C 6 -E 6 & 0.58 & 0.41 & -0.17 \\
C 68-E 7 & 0.58 & 0.31 & -0.27 \\
C 8 -E 8 & 0.20 & 0.22 & +0.02 \\
C 9 -E 9 & 0.23 & 0.41 & +0.18 \\
Mean ISD & & & $-0.06 \pm 0.20$ \\
$t$ & & & 0.60 \\
$P$ & & & $>0.50$
\end{tabular}

* $\Delta$, value for Mg-depleted animal minus value for control animal.

§ Dog C 6 was used as the control animal for two different Mg-depleted dogs (E 6, E 7), both of which were litter-mates of $\mathrm{C} 6$. 


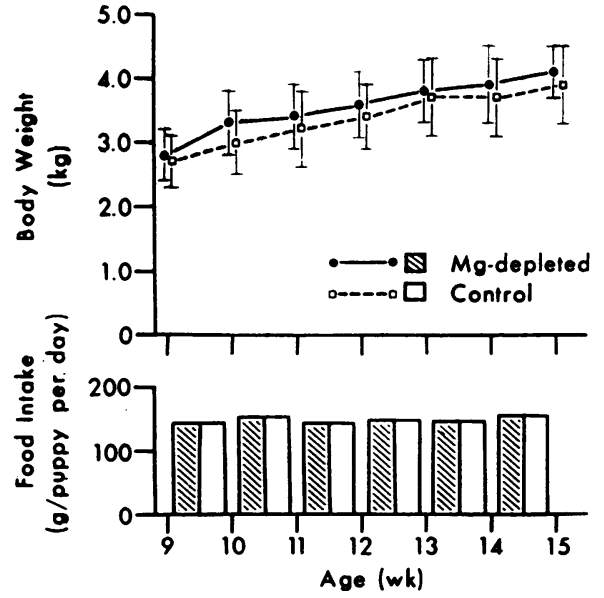

Figure 1 Average body weight and food intake of puppies fed on magnesium-deficient and control diets (study II). Vertical lines indicate \pm 1 sD of body weight. Six animals were used in each group.

ment to attain normocalcemia. We obtained no evidence that the PTE requirement was influenced by age of the animals or by the duration of the experimental diet, which extended for several months in some instances. There was a considerable variation in PTE requirement between animals within each group.

\section{Study II}

\section{EXPERIMENT}

As in study I, this study assessed responsiveness to PTE in magnesium-depleted dogs after thyroparathyroidectomy. However, the experimental design was more rigidly controlled and additional criteria of PTE responsiveness were applied.

The study was carried out in six litter-mate pairs o. purebred beagle puppies, all 9 wk of age and of almost equal starting weights (average weight $2.8 \mathrm{~kg}$ ). One animal of each pair received the magnesium-deficient synthetic diet ad lib for $6 \mathrm{wk}$; the litter-mate control animal was pair-fed the same amount of the control diet. Fasting plasma magnesium, calcium, inorganic phosphate, and alkaline phosphatase were measured weekly in all animals. At the age of $15 \mathrm{wk}$, thyroparathyroidectomy was carried out in pairs in all animals and responsiveness to PTE was assessed in both groups by determining $(a)$ the calcemia response to PTE, 0.3 $\mathrm{U} / \mathrm{kg}$ per hr; (b) the dose of PTE required to attain normocalcemia: and $(c)$ the regression lines of plasma calcium on PTE dose.

In addition, this study offered the opportunity to observe the effect of magnesium depletion on body weight, food intake, and blood chemistry, in a homogeneous group of animals.

\section{Results}

Body weight and food intake. Fig. 1 shows the average body weight and food intake of the animals during the $6 \mathrm{wk}$ on diet. The average weight of puppies receiving the magnesium-deficient diet increased from 2.8 to $4.1 \mathrm{~kg}$, and pair-fed puppies receiving the control diet showed a similar pattern of weight gain. The daily intakes ranged from 143 to $153 \mathrm{~g}$ per puppy for each group.

Effects of the experimental diets on chemical values in plasma. Weekly magnesium, calcium, inorganic phosphate, and alkaline phosphatase values are shown in Fig. 2. Plasma magnesium and calcium changes were similar to those observed in study I. In the puppies fed the magnesium-deficient diet, the plasma inorganic phosphate values increased to $9.7 \mathrm{mg} / 100 \mathrm{ml}$ by the $3 \mathrm{rd}$ wk and remained at this level. Plasma magnesium, calcium, and phosphate concentrations of magnesium-depleted and control animals were significantly different $(P<0.01)$ within $3 \mathrm{wk}$. There was no difference in the plasma alkaline phosphatase activity of magnesium-depleted and control animals.

The plasma-ionized calcium values were also decreased in magnesium-depleted animals when tested after $6 \mathrm{wk}$ on the diet (Table V). The percentage of calcium

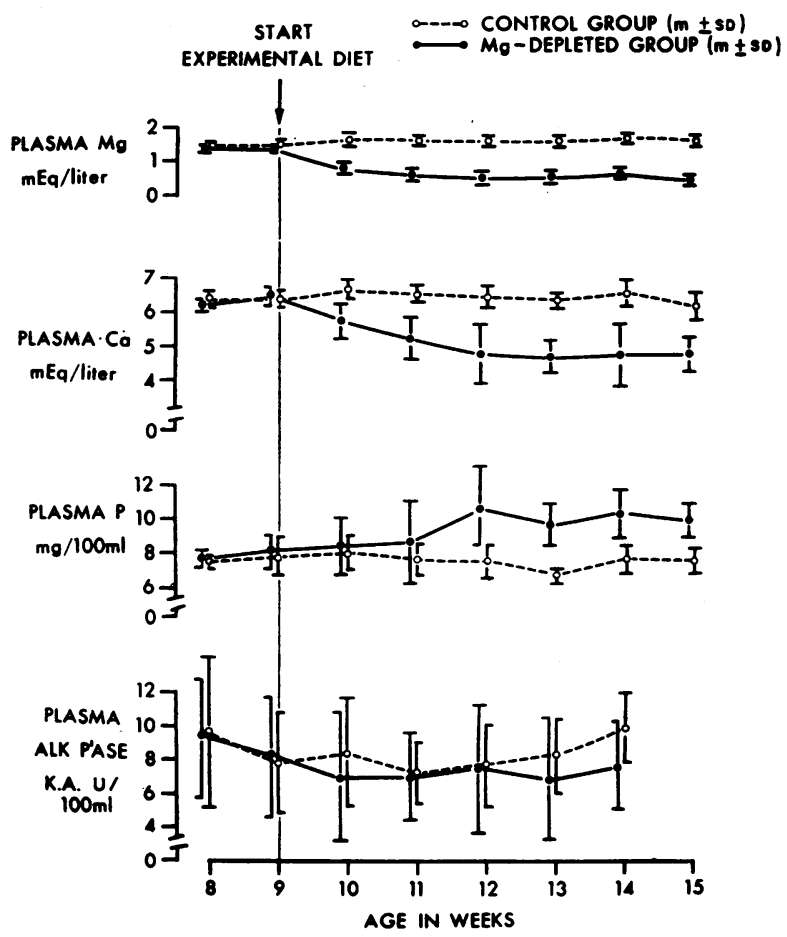

FIGURE 2 Fasting plasma magnesium, calcium, inorganic phosphate, and alkaline phosphatase values in puppies pairfed with magnesium-deficient and control diets (study II). Six animals were used in each group. 
TABLE V

Plasma Total Calcium, Ionized Calcium, pH and Total Protein in Fasting Puppies after

6 wk on the Experimental Diets

Study II

\begin{tabular}{|c|c|c|c|c|c|}
\hline & \multirow[b]{2}{*}{ Total $\mathrm{Ca}$} & \multirow[b]{2}{*}{$\mathrm{Ca}^{++}$} & \multirow{2}{*}{$\frac{\mathrm{Ca}^{++}}{\text {Total } \mathrm{Ca}} \times 100$} & \multicolumn{2}{|c|}{$\cdot$} \\
\hline & & & & $\mathrm{pH}$ & protein \\
\hline Control & $\begin{array}{c}m E q / \text { liter } \\
5.96 \pm 0.42\end{array}$ & $\begin{array}{c}m E q / \text { liter } \\
2.55 \pm 0.22\end{array}$ & $42.2 \pm 6.4$ & $7.34 \pm 0.08$ & $\begin{array}{c}g / 100 \mathrm{ml} \\
5.6 \pm 0.5\end{array}$ \\
\hline Mg-depleted & $4.48 \pm 0.52^{*}$ & $1.87 \pm 0.24^{*}$ & $43.0 \pm 4.8 \mathrm{NS}$ & $7.33 \pm 0.06 \mathrm{NS}$ & $5.1 \pm 0.7 \mathrm{~N}$ \\
\hline
\end{tabular}

$* P<0.01$.

NS, not significant.

in the ionized form was almost the same in the two groups of animals. The blood $\mathrm{pH}$ and total plasma protein showed no significant differences in magnesiumdepleted and control animals, and plasma sodium and potassium values were normal.

Effect of thyroparathyroidectomy on plasma calcium concentration. Plasma calcium concentration decreased in all animals $6 \mathrm{hr}$ after the operation (Fig. 3).

\section{Assessment of response to PTE.}

1. CALCEMIC RESPONSE TO PTE, 0.3 U/KG PER HR: Animals were fasted from $17 \mathrm{hr}$ preoperatively until $54 \mathrm{hr}$ after thyroparathyroidectomy. Intravenous infusion of PTE, $0.3 \mathrm{U} / \mathrm{kg}$ per $\mathrm{hr},{ }^{18}$ was started $6 \mathrm{hr}$ after the operation and was continued for $48 \mathrm{hr}$. The procedure was conducted in the fasting state to minimize the contribution of intestinal absorption of calcium. Plasma calcium values were determined four times, at 17, 24, 41, and $48 \mathrm{hr}$ of PTE infusion (Fig. 3), and the average plasma calcium value of each control and magnesium-depleted animal was calculated in the manner described earlier. The plasma calcium concentrations attained as a result of infusing PTE, $0.3 \mathrm{U} / \mathrm{kg}$ per $\mathrm{hr}$ were not significantly different in the two groups of puppies (Table VI).

2. DOSE OF PTE REQUIRED TO ATTAIN NORMOCALCEMIA: After the above experiment, the animals were pair-fed their previous diets, and the dose of PTE required to attain normocalcemia was determined. Table VII shows results for each of four pairs of puppies.

As in study $\mathrm{I}$, the PTE requirement varied considerably in spite of controlling the age and breed of the animals and the duration of the experimental diets. The

\footnotetext{
${ }^{12}$ Study I indicated that PTE in doses of $0.4 \mathrm{U} / \mathrm{kg}$ per $\mathrm{hr}$ would establish normocalcemia in thyroparathyroidectomized puppies whether fed the magnesium-deficient or the magnesium-supplemented diet. The dose of $0.3 \mathrm{U} / \mathrm{kg}$ per $\mathrm{hr}$ was chosen with the purpose of inducing only partial correction of hypocalcemia, which in turn would reduce the likelihood that the effect of PTE would be attenuated by other homeostatic mechanisms that limit hypercalcemia.
}

mean PTE doses required in the control and magnesiumdepleted groups were $0.38 \pm 0.05$ and $0.46 \pm 0.12 \mathrm{U} / \mathrm{kg}$

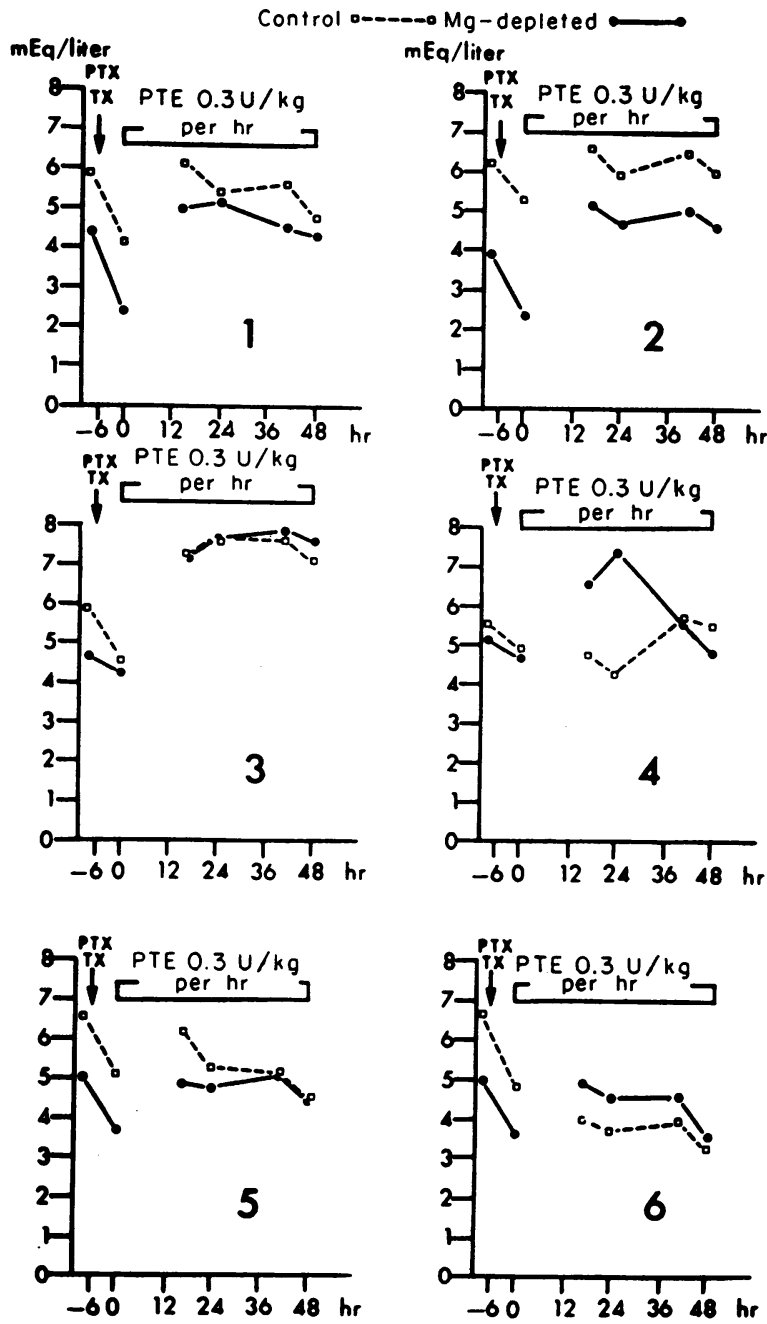

FIGURE 3 Plasma calcium concentrations in each pair of control and magnesium-depleted puppies (study II). Values are recorded preoperatively, $6 \mathrm{hr}$ after thyroparathyroidectomy (PTX, TX), and during the administration of PTE, $0.3 \mathrm{U} / \mathrm{kg}$ per $\mathrm{hr}$ for $48 \mathrm{hr}$. Animals were fasted throughout. 
TABLE VI

Average Plasma Calcium Concentration ( $m E q /$ liter) in each Puppy* during Infusion of PTE, $0.3 \mathrm{U} / \mathrm{kg}$ per $\mathrm{hr}$ Study II

\begin{tabular}{cllc}
\hline $\begin{array}{c}\text { Experimental } \\
\text { pair }\end{array}$ & Control & Mg-depleted & $\Delta$ Ca $\ddagger$ \\
\hline 1 & 5.47 & 4.71 & -0.76 \\
2 & 6.25 & 4.82 & -1.43 \\
3 & 7.42 & 7.58 & +0.16 \\
4 & 5.08 & 6.10 & +1.02 \\
5 & 5.24 & 4.79 & -0.45 \\
6 & 3.72 & 4.39 & +0.67 \\
Mean \pm SD & $5.53 \pm 1.24$ & $5.40 \pm 1.22$ & $-0.13 \pm 0.92$ \\
$t$ & & & 0.35 \\
$P$ & & & $>0.5$ \\
\hline
\end{tabular}

* Average of plasma Ca concentrations determined at 17, 24, 41 , and $48 \mathrm{hr}$ of PTE infusion. All animals were thyroparathyroidectomized and fasted.

$\ddagger \Delta \mathrm{Ca}=$ Plasma $\mathrm{Ca}_{\text {mg-depleted }}$-Plasma $\mathrm{Ca}_{\text {control. }}$.

per $\mathrm{hr}$ respectively, and these values were not statistically different (by paired $t$ test).

Because the PTE requirements determined in studies I and II were similar in magnitude and because it was shown in study I that the age and breed of animals, and the duration of magnesium depletion did not affect the PTE requirements to attain normocalcemia, the data obtained in these two studies were combined (Table VIII). The mean PTE doses required to attain normocalcemia in 15 control and 10 magnesium-depleted dogs were $0.42 \pm 0.14$ and $0.41 \pm 0.13 \mathrm{U} / \mathrm{kg}$ per $\mathrm{hr}$ respectively. These values were not statistically different.

3. REgRession aNALYSIS OF PLASMA ON PTE DOSE: Fig. 4 shows the regression lines relating the dose of PTE and the plasma calcium concentration in control

\section{TABLE VII}

PTE Dose Required to Attain the "Normocalcemic Value" in Control and Magnesium-Depleted Puppies Study II

\begin{tabular}{ccccc}
\hline & & \multicolumn{3}{c}{ PTE dose required } \\
\cline { 3 - 5 } $\begin{array}{c}\text { Experimental } \\
\text { pair }\end{array}$ & $\begin{array}{c}\text { "Normocalcemic } \\
\text { value" }\end{array}$ & Control & Mg-depleted & $\Delta^{*}$ \\
\hline & $m E q / l i t e r$ & & $U / k g$ per $h r$ & \\
1 & 6.10 & 0.31 & 0.49 & +0.18 \\
2 & 5.88 & 0.43 & 0.61 & +0.18 \\
3 & 5.89 & 0.38 & 0.43 & +0.05 \\
4 & 5.73 & 0.40 & 0.32 & -0.08 \\
Mean & 5.90 & 0.38 & 0.46 & +0.08 \\
\pm SD & \pm 0.15 & \pm 0.05 & \pm 0.12 & \pm 0.12 \\
$t$ & & & & 1.33 \\
$P$ & & & & $>0.10$
\end{tabular}

$* \Delta$, value for magnesium-depleted animal minus value for control animal.
TABLE VIII

Summary of PTE Requirements (U/kg per hr) to Attain the "Normocalcemic Value" in Thyroparathyroidectomized Dogs

\begin{tabular}{lllc}
\hline & \multicolumn{1}{c}{ Controls } & \multicolumn{1}{c}{ Mg-depleted } & $P$ \\
\hline Study I & $0.43 \pm 0.17(11)$ & $0.38 \pm 0.14(6)$ & $>0.50$ \\
Study II & $0.38 \pm 0.05(4)$ & $0.46 \pm 0.12(4)$ & $>0.10$ \\
Studies I and II & $0.42 \pm 0.14(15)$ & $0.41 \pm 0.13(10)$ & $>0.50$
\end{tabular}

The number of animals are noted in parentheses.

and magnesium-depleted animals after thyroparathyroidectomy. Each point in Fig. 4 represents the mean plasma calcium at each dose of PTE for each individual puppy. The regression lines of plasma calcium on PTE dose for the control and magnesium-depleted groups of animals were derived from these points. The regression coefficients and intercepts of the two lines were not significantly different indicating the similarity of the doseresponse relations of the two groups of animals.

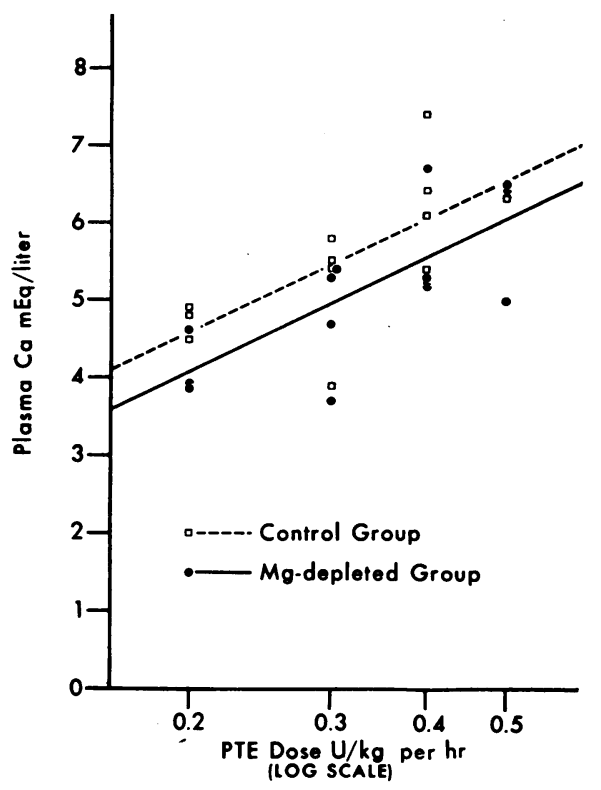

FIGURE 4 Regression-lines of plasma calcium concentrations and $\log$ dose of PTE in control and magnesium-depleted groups of puppies (study II). Four animals were used in each group. When regression lines are expressed as plasma $\mathrm{Ca}=\mathrm{A}+\mathrm{B} \log \mathrm{PTE}$ dose, the following values for A (intercept), B (regression coefficient) and $r$ (correlation coefficient) apply:

\begin{tabular}{lllc}
\hline & $\mathrm{A}$ & $\mathrm{B}$ & $r$ \\
\hline Control & 8.03 & 4.97 & 0.70 \\
Mg-depleted & 7.47 & 4.90 & 0.74 \\
$t$ & 0.569 & 0.034 & \\
$P$ & $>0.5$ & $>0.5$ & \\
\hline
\end{tabular}




\section{Study III}

\section{EXPERIMENT}

This study was carried out to investigate the influence of the intact thyroid glands on the dose of PTE required to attain normocalcemia in magnesium-depleted animals.

Five pairs of purebred litter-mate beagle puppies, aged 8-19 wk, were pair-fed the magnesium-deficient and control diets. The periods of pair-feeding ranged from 7 to $27 \mathrm{wk}$. Determinations of fasting plasma magnesium and calcium concentrations were made weekly on each animal.

In two of the magnesium-depleted puppies, the dose of PTE required to attain normocalcemia was also determined after thyroparathyroidectomy. This aspect of the study could not be investigated in the remaining three animals.

\section{Results}

The plasma magnesium and calcium concentrations of control and magnesium-depleted animals were similar to those observed in studies I and II. The dose of PTE required to attain normocalcemia in magnesium-depleted puppies with intact thyroid and parathyroid glands averaged $0.32 \mathrm{U} / \mathrm{kg}$ per hr (Table IX), a dose comparable to that observed in studies I and II. In two dogs, the dose required after thyroparathyroidectomy was similar to the corresponding preoperative requirement.

\section{DISCUSSION}

Normally the concentration of calcium in plasma is maintained within very narrow limits. Parathyroid hormone, probably the most important factor in maintaining calcium homeostasis, increases the concentration of calcium in extracellular fluid and plasma. In the state of magnesium depletion in man and several other animals, hypocalcemia is frequently a prominent associated finding. In our experimental model, restriction of dietary magnesium produced hypomagnesemia and this was accompanied by a decrease in the concentrations of total and ionized calcium in the plasma and an increase in the concentration of plasma phosphate, a picture pointing to a derangement in parathyroid physiology.

The present research was designed to assess parathyroid function in magnesium-depleted dogs by evaluating end-organ responsiveness to the calcemic action of PTE. In study I, the dose of PTE required to attain normocalcemia was determined in animals of various ages and breeds, and after various periods of magnesium restriction. In study II, the same assessment was carried out in pair-fed, litter-mate beagle puppies, all of the same age and with the same period of magnesium restriction. Despite more exacting control of variables in the second study, the results were similar and there were no signifi-
TABLE IX

\begin{tabular}{ccc}
$\begin{array}{c}\text { PTE Dose Required to Attain the "Normocalcemic Value" in } \\
\text { Intact Magnesium-Depleted Puppies } \\
\text { Study III }\end{array}$ \\
\hline Dog No. & "Normocalcemic value" & PTE dose required \\
\hline & $m E q /$ liter & $U / k g$ per $h r$ \\
598 & 5.65 & $0.52\left(0.62^{*}\right)$ \\
613 & 6.10 & $0.29\left(0.22^{*}\right)$ \\
585 & 5.68 & 0.31 \\
600 & 6.08 & 0.31 \\
765 & 6.07 & 0.16 \\
Mean \pm SD & $5.92 \pm 0.23$ & $0.32 \pm 0.13$
\end{tabular}

* After thyroparathyroidectomy.

cant differences in the PTE requirements of magnesiumdepleted and control animals.

In study II, additional aspects of PTE responsiveness were evaluated. The calcemic response to a set dose of PTE was studied in fasting thyroparathyroidectomized animals, the dose-response relations between PTE dose and plasma calcium concentration were compared in the two groups. When a set dose of PTE was infused, both magnesium-depleted and control groups of animals showed a clear-cut calcenic response. Furthermore, there was no difference in the concentration of plasma calcium attained during $48 \mathrm{hr}$ of hormone infusion. Fluctuations occurred in the plasma calcium levels of animals in both groups, even though PTE was being infused at a constant rate; presumably these fluctuations occurred because thyroparathyroidectomy had deprived the animals of normal homeostatic mechanisms. A comparison of regression lines of plasma calcium on PTE dose between the control and magnesium-depleted groups of animals showed similar dose-response relations in both groups.

From these experiments, magnesium-depleted animals are responsive to $\mathrm{PTE}$, and further the degree of responsiveness is similar to that of control animals. The hypocalcemia observed in magnesium-depleted animals could not be explained by refractoriness to parathyroid hormone.

Because studies I and II were carried out in thyroparathyroidectomized animals, it was not possible to rule out excess calcitonin as a cause of hypocalcemia. This hypothesis was evaluated in study III. In magnesium-depleted animals with intact thyroid and parathyroid glands, the dose of PTE required to attain normocalcemia was similar to that of magnesium-depleted animals that had undergone thyroparathyroidectomy. Thus, excessive secretion of calcitonin is ruled out as the cause of the hypocalcemia observed in the magnesium-depleted state.

The similar dose-response relations between the 
TABLE X

Plasma Calciumand Magnesium Values in Rats after 21 Days on the Experimental Diets. (Groups Pair-Fed to the Low Ca., Low Mg Group)

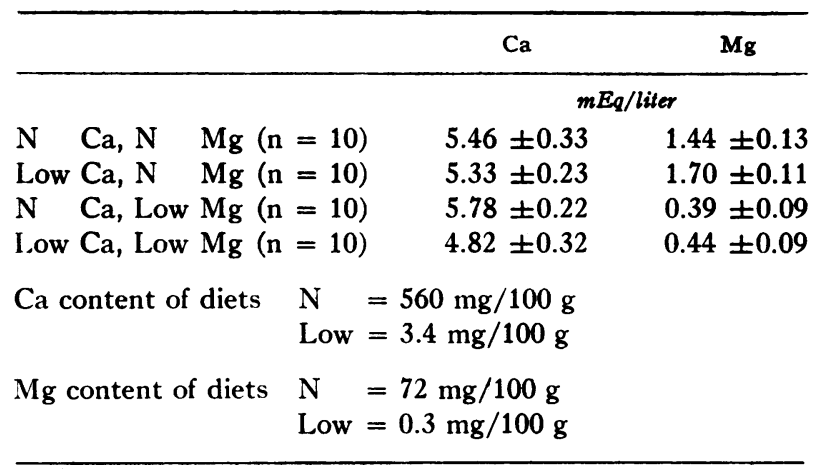

plasma calcium concentration and PTE dose in magnesium-depleted and control puppies of study II indicate that excessively rapid inactivation of circulating parathyroid hormone does not account for the hypocalcemia of magnesium depletion.

Theoretically, other metabolic or physiochemical factors favoring deposition or inhibiting resorption of bone calcium and factors causing negative calcium balance could contribute to the development of hypocalcemia. The similar amount of PTE required to maintain normocalcemia in both groups of animals makes it unlikely that these factors contributed to hypocalcemia.

Having discarded these possibilities as the cause of hypocalcemia, we now propose the hypothesis that the hypocalcemia observed in our magnesium-depleted puppies was due to impaired synthesis or diminished secretion of parathyroid hormone. This implies that magnesium is necessary for the normal function of the parathyroid gland. Because thyroparathyroidectomy caused a further decrease in the plasma calcium concentration in magnesium-depleted puppies, the parathyroid glands obviously had been releasing a certain amount of active parathyroid hormone-an amount which, according to hypothesis, was insufficient to maintain normocalcemia-and the end-organs were responsive to the parathyroid hormone released.

The clear-cut responsiveness of end-organs to the calcemic action of PTE in our magnesium-depleted animals is consistent with the observations in patients with primary hypomagnesemia $(10,19-21)$. These patients showed a prompt increase in plasma calcium concentration in response to PTE administration. On the other hand, several hypomagnesemic patients with chronic alcoholism (22) or steatorrhea (23) failed to show a calcemic response to PTE. Some of the alcoholic patients were hypocalcemic in spite of normomagnesemia (22), and one of the patients with steatorrhea remained refractory to the calcemic action of PTE after magnesium repletion (23). Thus factors other than hypomagnesemia may have been involved in the refractoriness of these patients to parathyroid hormone.

In rats, a typical consequence of magnesium depletion is hypercalcemia $(4,24-28)$, and it is widely held that hypomagnesemia causes hyperactivity of the parathyroid glands in this species $(24,27-29)$. However, MacManus and Heaton (30) observed that hypocalcemia occurred in magnesium-depleted rats if, in addition, the dietary calcium was restricted, and we have confirmed this finding by feeding rats a diet containing $0.3 \mathrm{mg}$ magnesium and $3.4 \mathrm{mg}$ calcium per $100 \mathrm{~g}$ diet (Table X). MacManus and Heaton attributed the hypocalcemia of their rats to a reduced rate of bone catabolism caused by the direct effect of magnesium deficiency on bone. They ascribed hypercalcemia in magnesium-deficient rats receiving a liberal calcium intake to enhanced intestinal absorption of calcium, either in response to the secretion of additional parathyroid hormone or because of reduced competition from magnesium for a common transport mechanism in the intestine. However, in view of the evidence that magnesium-deficient rats show a hypercalcemic response to parathyroid extract $(27,30,31)$, it is tempting to suggest as an alternative hypothesis that there is a defect in parathyroid function in magnesium-depleted rats, as we have proposed for the magnesium-depleted puppies. Thus, the magnesium-depleted rat on a low calcium intake would develop hypocalcemia not because of a primary reduction in rate of bone catabolism but because of a deficiency of parathyroid hormone. Hypocalcemia can be readily controlled in the parathyroidectomized rat by feeding a liberal intake of calcium, presumably because of an unusually high efficiency of intestinal calcium absorption (32). Further, magnesiumdepletion per se enhances intestinal calcium absorption in the rat $(33,34)$. We propose that hypercalcemia in the magnesium-depleted rat receiving a liberal intake of calcium might be explained by the overriding effects of these two factors causing increased intestinal calcium absorption despite diminished parathyroid function.

Buckle, Care, Cooper, and Gitelman (35) have shown that, when isolated thyroid and parathyroid glands of goats and sheep were perfused in situ, the concentration of parathyroid hormone in the effluent plasma varied inversely with the magnesium concentration of the perfused blood. Similar relationships were demonstrated in vitro by Sherwood, Herrmann, and Bassett (36). These responses are attributable to a different physiological phenomenon than the one we are investigating, and are not in contradiction to our findings. The animals employed for the above two studies were not magnesiumdepleted, nor were the ambient magnesium concentrations as low as in our animals. On the other hand, 
Targovnik, Rodman, and Sherwood (37) have shown recently that the release of parathyroid hormone was diminished when bovine parathyroid glands were incubated in media containing very low concentrations of magnesium $(<0.3 \mathrm{~mm})$. This finding is consistent with our hypothesis regarding the causation of hypocalcemia in the magnesium-depleted dog.

\section{ACKNOWLEDGMENTS}

We wish to acknowledge the expert technical assistance of Miss Dianne Chapman. We thank Dr. I. C. Radde for determining plasma-ionized calcium values, and we thank her and Dr. Sang Whay Kooh for much interest and helpful criticism throughout the entire investigation.

This work was supported by the Medical Research Council, Ottawa, Canada, grant MA 2131.

\section{REFERENCES}

1. Suh, S. M., and D. Fraser. 1970. End-organ responsiveness to parathyroid hormone in magnesium-depleted puppies. Clin. Res. 18: 722. (Abstr.)

2. Shils, M. E. 1969. Experimental human magnesium depletion. Medicine (Baltimore). 48: 61 .

3. Bunce, G. E., K. J. Jenkins, and P. H. Phillips. 1962. The mineral requirements of the dog. III. The magnesium requirement. J. Nutr. 76: 17.

4. Chiemchaisri, Y., and P. H. Phillips. 1963. Effect of dietary fluoride upon the magnesium calcinosis syndrome. J. Nutr. $81: 307$.

5. Smith, R. H. 1961. Importance of magnesium in the control of plasma calcium in the calf. Nature (London). $191: 181$.

6. Larvor, P., A. Girard, M. Brochart, A. Parodi, and J. Sevestre. 1964. Etude de la carence expérimentale en magnésium chez le veau. I. Observations cliniques, biochimiques et anatomopathologiques. Ann. Biol. Anim. Biochim. Biophys. 4: 345 .

7. Miller, E. R., D. E. Ullrey, C. L. Zutaut, B. V. Battzer, D. A. Schmidt, J. A. Hoefer, and R. W. Luecke. 1965. Magnesium requirement of the baby pig. J. Nutr. 85: 13.

8. McAleese, D. M., and R. M. Forbes. 1959. Experimental production of magnesium deficiency in lambs on a diet containing roughage. Nature (London). 184: 2025.

9. Paunier, L., I. C. Radde, S. W. Kooh, and D. Fraser. 1965. Primary hypomagnesemia with secondary hypocalcemia. J. Pediat. 67: 945. (Abstr.)

10. Paunier, L., I. C. Radde, S. W. Kooh, P. E. Conen, and D. Fraser. 1968. Primary hypomagnesemia with secondary hypocalcemia in an infant. Pediatrics. 41: 385.

11. Kahil, M. E., J. E. Parrish, E. L. Simons, and H. Brown. 1966. Magnesium deficiency and carbohydrate metabolism. Diabetes. 15: 734.

12. Munson, P. L. 1961. Biological assay of parathyroid hormone. In The Symposium on Advances in Parathyroid Research, Rice University. R. O. Greep and R. V. Talmage, editors. Charles C Thomas, Publisher, Springfield, IIl. 94.

13. Alcock, N., I. MacIntyre, and I. Radde. 1960. The determination of magnesium in biological fluids and tissues by flame spectrophotometry. J. Clin. Pathol. (London). 13: 506 .
14. MacIntyre, I. 1961. Flame photometry. Advan. Clin. Chem. 4: 1 .

15. Gomori, G. 1942. A modification of the colorimetric phosphorus determination for use with the photoelectric colorimeter. J. Lab. Clin. Med. 27: 955.

16. Wootton, I. D. P. 1964. Micro-Analysis in Medical Biochemistry. J. \& A. Churchill Ltd., London, England. 4th edition. 101.

17. Radde, I. C., B. Höffken, and D. K. Parkinson. 1971. Practical aspects of a measurement technique for calcium ion activity in plasma. Clin. Chem. 17: 1002.

18. Snedecor, G. W., and W. G. Cochran. 1967. Statistical Methods. The Iowa State University Press, Ames, Iowa. 6th edition.

19. Salet, J., C. Polonovski, C. F. De Gouyon, G. Pean, B. Melekian, and J.-P. Fournet. 1966. Tétanie hypocalcemique récidivante par hypomagnesémie congénitale: une maladie metabolique nouvelle. Arch. Fr. Pediat. 23: 749.

20. Skyberg, D., J. H. Strømme, R. Nesbakken, and K. Harnaes. 1968. Neonatal hypomagnesemia with selective malabsorption of magnesium. A clinical entity. Scand. J. Clin. Lab. Invest. $21: 355$.

21. Str $\phi$ mme, J. H., R. Nesbakken, T. Normann, F. Skjør ten, D. Skyberg, and B. Johannessen. 1969. Familial hypomagnesemia. Biochemical, histological and hereditary aspects studied in two brothers. Acta Paediat. Scand. 58: 433 .

22. Estep, H., W. A. Shaw, C. Watlington, R. Hobe, W. Holland, and St. G. Tucker. 1969. Hypocalcemia due to hypomagnesemia and reversible parathyroid hormone unresponsiveness. J. Clin. Endocrinol. Metab. 29: 842.

23. Muldowney, F. P., T. J. McKenna, L. H. Kyle, R. Freaney, and M. Swan. 1970. Parathormone-like effect of magnesium replenishment in steatorrhea. N. Engl. J. Med. $282: 61$.

24. MacIntyre, I., and D. Davidsson. 1958. The production of secondary potassium depletion, sodium retention, nephrocalcinosis and hypercalcaemia by magnesium deficiency. Biochem. J. 70: 456.

25. Whang, R., and L. G. Welt. 1963. Observations in experimental magnesium depletion. J. Clin. Invest. 42:305.

26. Martindale, L., and F. W. Heaton. 1964. Magnesium deficiency in the adult rat. Biochem. J. 92: 119.

27. Heaton, F. W. 1965. The parathyroid glands and magnesium metabolism in the rat. Clin. Sci. (London). 28: 543.

28. Gitelman, H. J., S. Kukolj, and L. G. Welt. 1968. The influence of the parathyroid glands on the hypercalcemia of experimental magnesium depletion in the rat. J. Clin. Invest. $47: 118$.

29. Gitelman, H. J., and L. G. Welt. 1969. Magnesium deficiency. Annu. Rev. Med. 20: 233.

30. MacManus, J., and F. W. Heaton. 1969. The effect of magnesium deficiency on calcium homeostasis in the rat. Clin. Sci. (London). 36: 297.

31. Chase, L. R., and T. J. Hahn. 1970. Effect of parathyroid hormone (PTH) on cyclic nucleotides in normal and hypomagnesemic rats. Clin. Res. 18: 622. (Abstr.)

32. Bronner, F. 1960. Dynamics and function of calcium. In Mineral Metabolism. C. L. Comar, and F. Bronner, editors. Academic Press, Inc., New York. 2(Pt. A) : 341.

33. Alcock, N., and I. MacIntyre. 1962. Inter-relation of calcium and magnesium absorption. Clin. Sci. (London). 22: 185 . 
34. Kessner, D. M., and F. H. Epstein. 1966. Effect of magnesium deficiency on gastrointestinal transfer of calcium. Proc. Soc. Exp. Biol. Med. 122: 721.

35. Buckle, R. M., A. D. Care, C. W. Cooper, and H. J. Gitelman. 1968. The influence of plasma magnesium concentration on parathyroid hormone secretion. J. Endocrinol. Metab. 42 : 529.
36. Sherwood, L. M., I. Herrmann, and C. A. Bassett. 1969. In vitro studies of normal and abnormal parathyroid tissue. Arch. Intern. Med. 124: 426.

37. Targovnik, J. H., J. S. Rodman, and L. M. Sherwood. 1971. Regulation of parathyroid hormone secretion in vitro: quantitative aspects of calcium and magnesium ion control. Endocrinology. 88: 1477. 